\title{
Population biology of green sea urchins on rocky barrens*
}

\author{
John H. Himmelman \\ Département de biologie et GIROQ (Groupe interuniversitaire de Recherches océanographiques de Québec), Université Laval, \\ Québec G1K 7P4, Canada
}

\begin{abstract}
Populations of the sea urchin Strongylocentrotus droebachiensis in highly grazed rocky barrens in eastern Newfoundland were sampled quantitatively in summer 1968. Comparisons among populations at an extremely exposed, a moderately exposed and a protected site show differences in recruitment and/or juvenile survival, mortality and growth which may be caused by differences in temperature, wave exposure and food availability. Dense populations have an unusual growth pattern. Juveniles grow very slowly and at a certain point growth can virtually stop causing the formation of a stationary mode composed of several year classes of juveniles. The position of this conglomerate mode varies from 8 to $11 \mathrm{~mm}$ in test diameter at different locations or depths. Urchins larger than 15 to $20 \mathrm{~mm}$ have a much higher growth rate. I hypothesize that the slow growth of juvenile urchins in dense populations is due to a severe food shortage coupled to their low mobility. Urchins larger than 15 to $20 \mathrm{~mm}$ move actively about searching for macroalgal food; it is postulated that their increased growth rate is due to their mobility and resultant greater access to food. If any of the larger actively foraging urchins were to die they would be replaced by the ever abundant juveniles, thus assuring the persistence of urchin-dominated barrens.
\end{abstract}

\section{INTRODUCTION}

Green sea urchins Strongylocentrotus droebachiensis are abundant in rocky bottom subtidal communities along the northeastern coast of North America (Himmelman 1969, 1985, Neish 1973, Fletcher et al. 1974b, MacKay 1976, Hooper 1980, Himmelman et al. 1983a,b, Keats et al. 1984a,b, 1985, Himmelman \& Lavergne 1985, Miller 1985a) as well as over a large part of coastal areas of the North Atlantic and North Pacific (Grieg 1928, Shelford et al. 1935, Madsen 1936, Kuznetzov 1946, Propp 1964, 1966, Foreman 1977, Hagen 1983). Their grazing activities severely limit the distribution of macrophytes (Breen \& Mann 1976, Foreman 1977, Himmelman et al. 1983b, Himmelman 1985). Urchin-dominated communities support only crustose coralline algae and a few grazing-resistant (non-preferred) fleshy macroalgae and have thus been called 'barren grounds' (Lawrence 1975). Urchin-dominated barrens are geographically widespread, and can persist for long periods (Himmelman et al. 1983a). I

\footnotetext{
- Contribution to the programmes of GIROQ and the Marine Sciences Research Laboratory of Memorial University of Newfoundland, Canada
}

made quantitative transects through urchin-dominated communities in Newfoundland to examine the structure of urchin populations under varying environmental conditions (Himmelman 1969). Further repetitive sampling was made at 3 sites to follow temporal changes in urchin populations. At that time (and for a considerable time later) the literature on urchin growth indicated that juveniles increase their diameter by 5 to $17 \mathrm{~mm}$ annually (Grieg 1928, Swan 1958, Miller \& Mann 1973). Based on this information, it was difficult to interpret the structure of these urchin populations with their well defined and nearly stationary modes of small urchins. I later encountered similar size distributions with well defined modes of small urchins in urchin-dominated communities in the St. Lawrence Estuary and made repetitive observations over a 2 to $5 \mathrm{yr}$ period to examine the growth of juveniles (Himmelman et al. 1983a, b). These studies demonstrated that in dense urchin populations juvenile urchins grow only 1 to $2 \mathrm{~mm}$ annually. The purpose of this study is to present a new analysis of the structure of the Newfoundland urchin populations. A small size class interval, suitable for detecting very slow growth rates, is employed and indicates an unusual pattern of growth in dense populations. 


\section{METHODS AND STUDY AREAS}

During summer 1968, quantitative samples were collected using SCUBA at different depths following a compass bearing at 3 locations on the Avalon Peninsula, eastern Newfoundland. For a specific depth in a given transect usually six $0.2 \mathrm{~m}^{2}$ quadrats were sampled. The first quadrat was placed at random, by blindly swimming towards or sinking to the bottom; subsequent ones were placed systematically in a horizontal series, each quadrat one quadrat width from the preceeding one. The urchins within each quadrat were transferred to a fine mesh collecting bag. Great care was taken to assure thorough sampling and often 20 to $30 \mathrm{~min}$ were spent examining one $0.2 \mathrm{~m}^{2}$ quadrat. Loose material was usually transferred to the collecting bag and later examined in the laboratory; encrusting coralline algae on bedrock were either carefully inspected underwater or chipped away and transferred to the laboratory for later inspection. In the laboratory the diameter (to the nearest $0.1 \mathrm{~mm}$ ) and live weight (to nearest $0.01 \mathrm{~g}$ after allowing the urchin to drain on paper towelling for $15 \mathrm{~min}$ ) were measured for each urchin. Transect sites were as follows:

Logy Bay. This area faces the open North Atlantic and thus receives extremely heavy wave action (Fig. 1). A steep bedrock slope was the predominant substratum. Samples were taken at 8 different depths starting at $5 \mathrm{~m}$ below lowest water of spring tides (LWST), just below the subtidal Alaria esculenta fringe, and continuing to $24 \mathrm{~m}$ depth.

Portugal Cove. As this location is $21 \mathrm{~km}$ inside of Conception Bay and is protected by a large island to the west (Fig. 1), it receives much less wave action than Logy Bay. Sampling was done near a rocky point at the southern entrance to the cove on a mixture of bedrock outcrops and loose substrata. One transect was made in a line running northwest of the rocky point along a gently sloping bedrock bottom. Samples were taken starting in a tidal pool near low tide level, next at $3 \mathrm{~m}$, just below the Alaria esculenta fringe, then continuing at $3 \mathrm{~m}$ depth intervals to $15 \mathrm{~m}$ depth, near the lower limit of the bedrock substratum. A second transect was made from near low tide level to $21 \mathrm{~m}$ over loose substratum located more towards the interior of the cove.

Holyrood. This protected area is near the innermost part of Conception Bay (Fig. 1). There was a cobble bottom in shallow water, predominantly gravel and mud from 3 to $10 \mathrm{~m}$ deep, and small cobbles and gravel below $11 \mathrm{~m}$. Due to the small numbers of urchins at this site a larger quadrat size $\left(0.8\right.$ or $\left.1.0 \mathrm{~m}^{2}\right)$ was used.

At a depth of $5 \mathrm{~m}$ at Logy Bay, $3 \mathrm{~m}$ on bedrock at Portugal Cove, and $15 \mathrm{~m}$ on loose substratum at Portugal Cove, sampling was repeated in spring and late summer of the next year to follow the growth of cohorts which were well defined at these sites.

Population structure was examined by visually examining the size-frequency distributions with $1 \mathrm{~mm}$ size classes. Distributions for different depths were examined together because interpretations not consistent for the various depths must be rejected. While in the majority of the distributions recent cohorts were well defined, occasionally the data for a particular depth were less well defined. In such cases I took the data for lesser and greater depths into consideration in estimating the position of year classes.

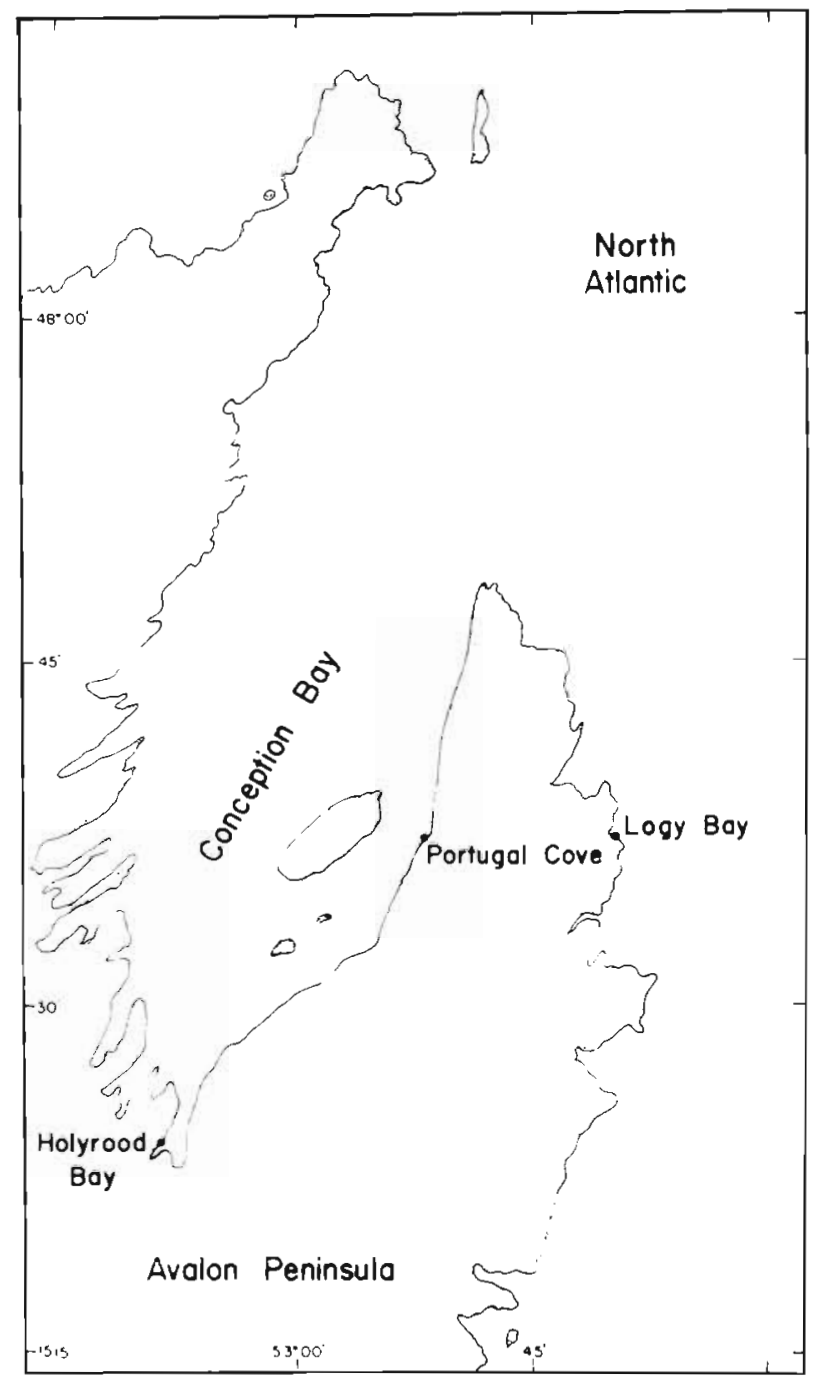

Fig. 1. Northeast portion of Avalon Peninsula, Newfoundland, showing locations where subtidal transects were made

\section{RESULTS}

\section{Density and biomass}

Histograms showing total density and biomass of Strongylocentrotus droebachiensis at each depth sam- 
pled in the 4 transects, and the contribution of small $(<20 \mathrm{~mm}$ in test diameter), intermediate-sized (20 to $40 \mathrm{~mm}$ ), and large (>40 mm) urchins to the totals, are given in Fig. 2. In the bedrock transect at Logy Bay, density decreased with depth, from 350 urchins $\mathrm{m}^{-2}$ at $5 \mathrm{~m}$ depth to 80 to 100 urchins $\mathrm{m}^{-2}$ at 18 to $24 \mathrm{~m}$. Biomass was greatest at $8 \mathrm{~m}, 2.5 \mathrm{~kg} \mathrm{~m}^{-2}$; it decreased with increasing depth to 0.6 to $0.8 \mathrm{~kg} \mathrm{~m}^{-2}$ at 18 to $24 \mathrm{~m}$. During the sampling period, biomass was slightly lower at $5 \mathrm{~m}$ than at $8 \mathrm{~m}$ due to the greater numbers of large urchins at $8 \mathrm{~m}$. However, large urchins can move about to a considerable extent. During calm periods, when they move to shallower water to graze on algae
(Himmelman 1985), peak biomass undoubtedly occurs just below the Alaria esculenta fringe.

Density and biomass also decreased with depth in the bedrock transect at Portugal Cove. However, at comparable depths, values were lower than at Logy Bay. Thus, density and biomass at $3 \mathrm{~m}$ depth at Portugal Cove were similar to the values at $8 \mathrm{~m}$ at Logy Bay. While quantitative samples were not collected from within the Alaria esculenta fringe at Logy Bay and Portugal Cove, I observed that urchins were scarce. The urchins present almost always had short, blunt spines.

In contrast to the pattern in the above transects, on
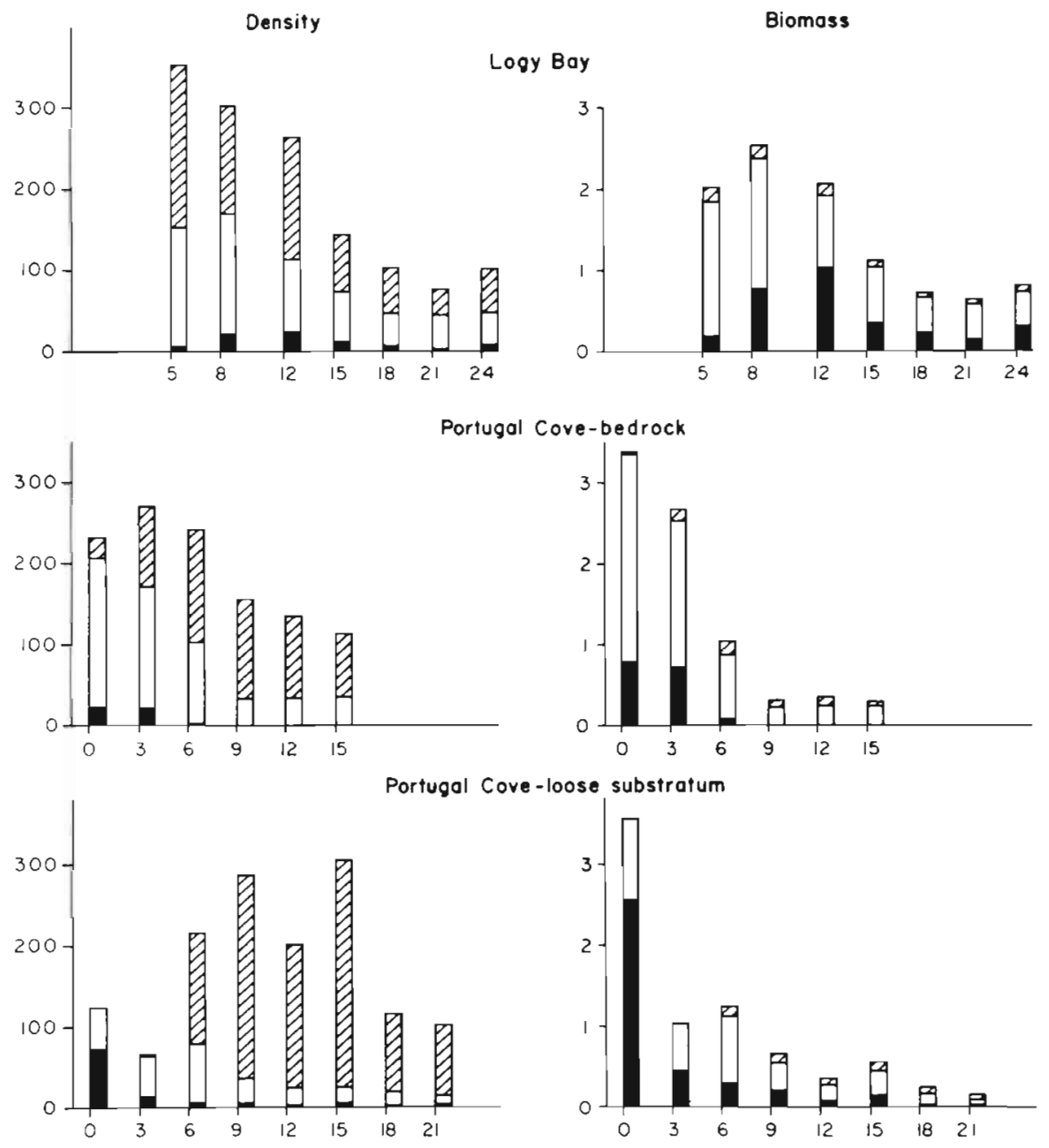

Fig. 2. Strongylocentrotus droebachiensis. Density and biomass in relation to water depth in the 4 subtidal transects

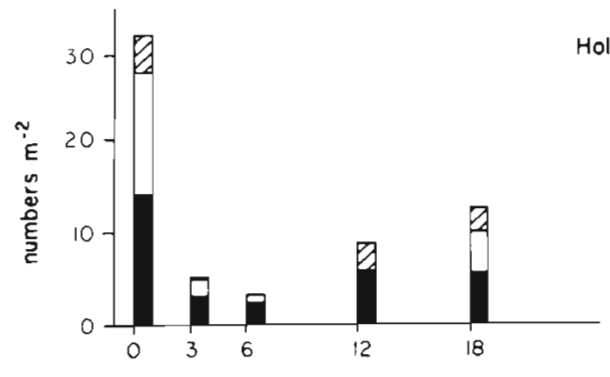

Holyrood Bay

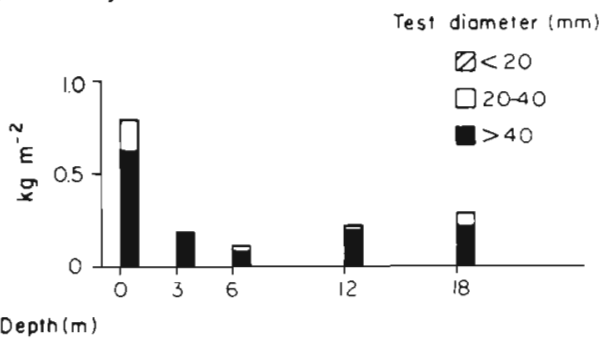


loose substratum at Portugal Cove, density increased with increasing depth to a peak at $15 \mathrm{~m}$ depth. This was due to small urchins, as intermediate-sized and large urchins decreased in numbers with depths as in the other transects. The rocks found in shallow water in this transect were well scoured due to wave action. If small urchins settle in this area, they would likely be crushed. The rock material became more stable with depth, as evidenced by the increased abundance of the crustose coralline algae Lithothamnium glaciale, and the irregular surfaces supported large numbers of small urchins (Fig.3). As small urchins contributed little to total biomass, biomass decreased with increasing depth as in the other transects.

At Holyrood urchin densities were lower than at Logy Bay and Portugal Cove by a factor of $\approx 10$ (note change in scale in Fig. 2). Peak density was 32 urchins $\mathrm{m}^{-2}$ at $0 \mathrm{~m}$. At 3 and $6 \mathrm{~m}$ there was a mud and gravel bottom and density was very low. It increased slightly at 12 and $18 \mathrm{~m}$ depth where the substratum was coarser. At Holyrood a peak biomass of $0.8 \mathrm{~kg} \mathrm{~m}^{-2}$ occurred near the LWST level.
Thus, urchin density and biomass increased between Holyrood in the innermost part of Conception Bay and Logy Bay at the exterior of Conception Bay. At Holyrood the low density of small urchins suggested a low rate of recruitment or juvenile survival. By contrast, at the more exposed sites, Portugal Cove and Logy Bay, the great abundance of juveniles indicates that recruitment and/or juvenile survival rate were high, especially on substrata with abundant small crevices such as Lithothamnium covered bottoms. At all 3 locations the greatest abundance of urchins was found in shallow water or just below the subtidal algal fringe, and abundance generally decreased at greater depth.

\section{Population size-structure}

One to several modes of small urchins were evident in the size-frequency distributions in all 4 transects (Fig. 4, 5, 6\& 7). A particularly prominent mode was situated at 7.5 to $10.0 \mathrm{~mm}$ in test diameter at Logy Bay, at 6.0 to $10.7 \mathrm{~mm}$ at Portugal Cove, and at 10 to $12 \mathrm{~mm}$

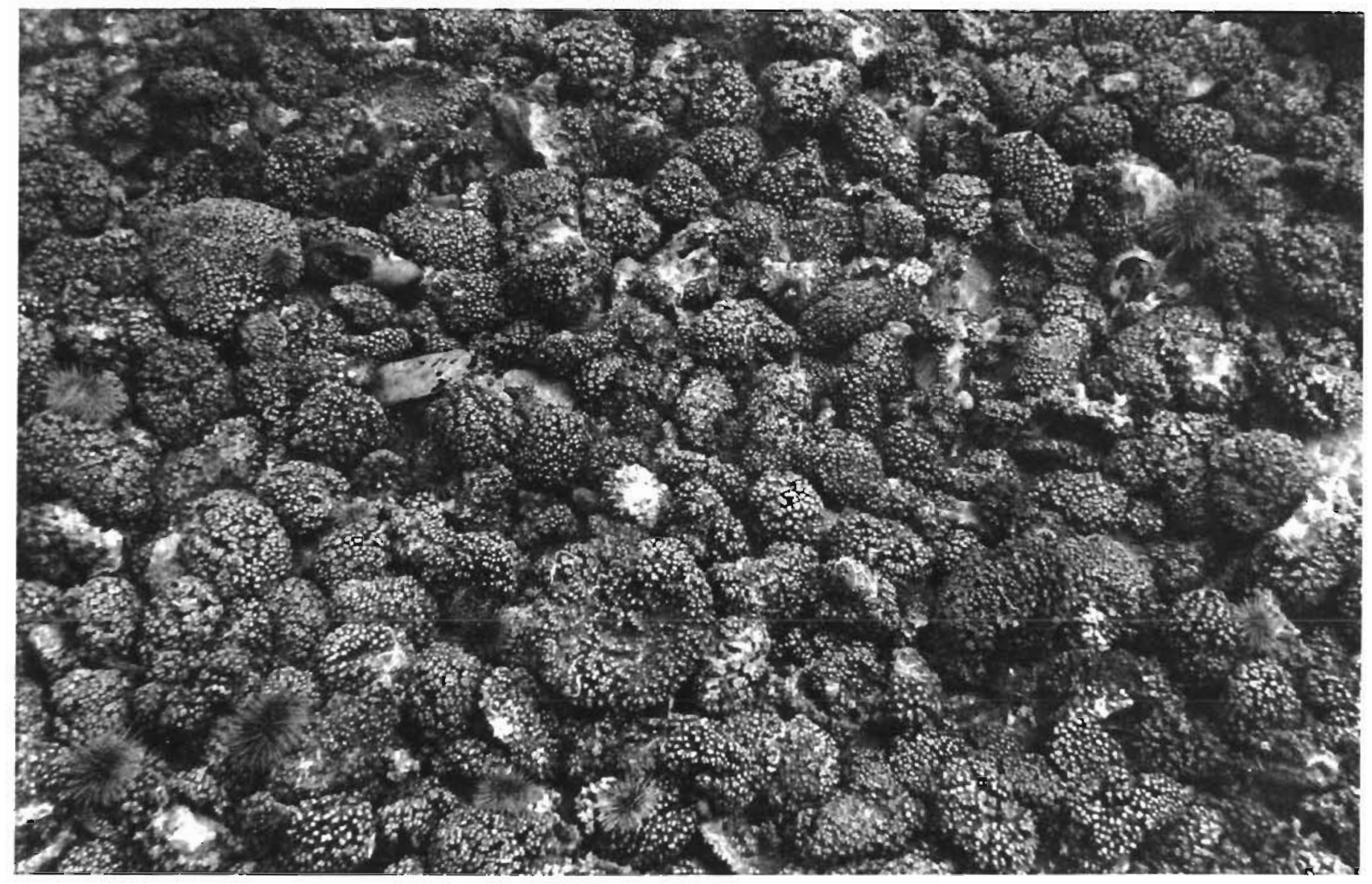

Fig. 3. Loose substratum bottom, heavily encrusted with Lithothamnium glaciale, 15 m water depth at Portugal Cove. Density of urchins was ca $309 \mathrm{~m}^{-2} ; 92 \%$ of the urchins measured $<20 \mathrm{~mm}$ in test diameter. In this habitat a strong and stationary mode of urchins at $10.5 \mathrm{~mm}$ was observed over a 14 mo period 

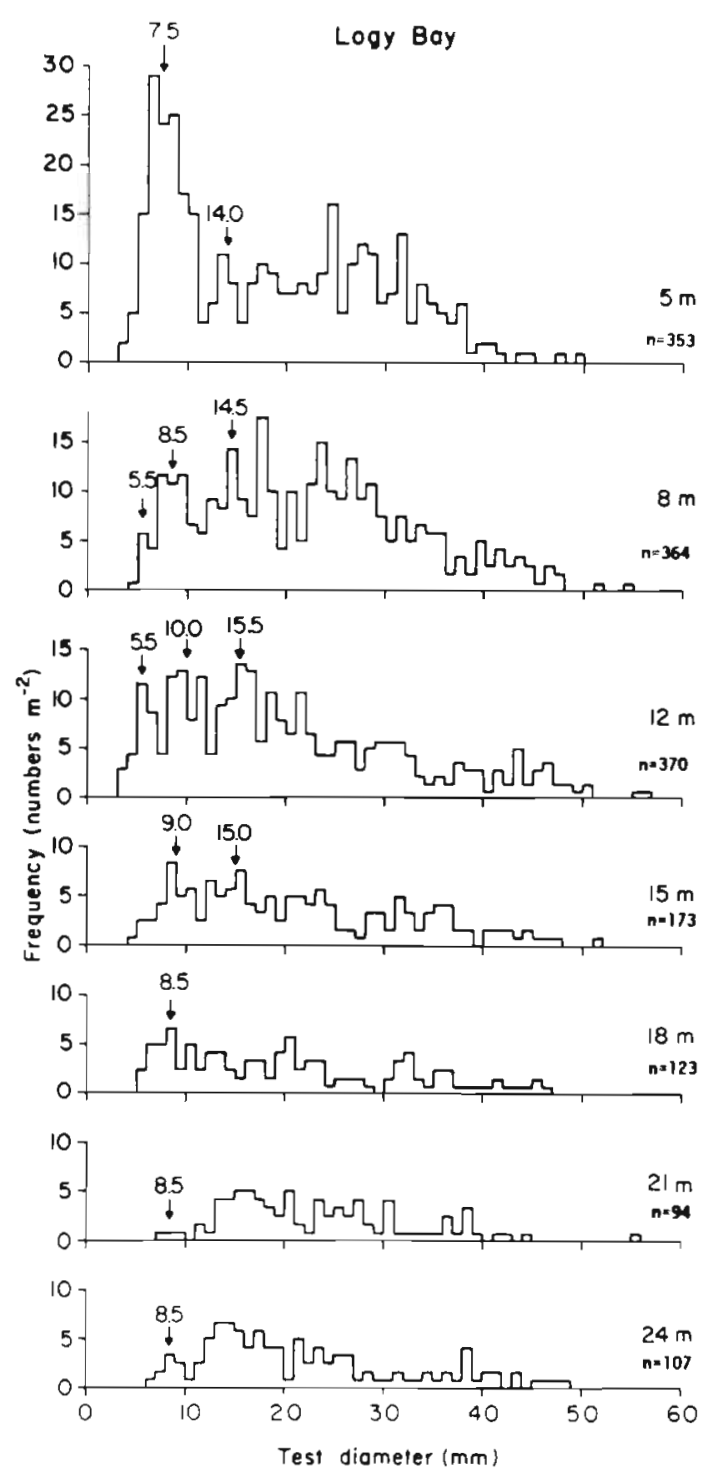

Fig. 4. Strongylocentrotus droebachiensis. Size-frequency distributions at different water depths of Logy Bay. Numbers over histograms indicate positions of cohorts discussed in the text

at Holyrood. A smaller mode was evident at 3.5 to $5.5 \mathrm{~mm}$ at some depths at Logy Bay and Portugal Cove. There was a suggestion of a third mode of juvenile urchins at 14 to $15.5 \mathrm{~mm}$ at Logy Bay, at 10 to $11 \mathrm{~mm}$ in the bedrock transect at Portugal Cove, and at 10.5 to $15 \mathrm{~mm}$ in the loose substratum transect at Portugal Cove.

Repetitive sampling showed the growth of juvenile urchins over 13 to $14 \mathrm{mo}$ (Fig. 8). Just below the Alaria zone at Logy Bay $(5 \mathrm{~m}$ deep), the mode at $7.5 \mathrm{~mm}$ in diameter in early July 1968 was at $10.5 \mathrm{~mm}$ by late May 1969, but did not change during summer 1969. More rapid growth occurred just below the Alaria zone at Portugal Cove ( $3 \mathrm{~m}$ deep). The mode at $8.5 \mathrm{~mm}$ on August 1968 was at $12.5 \mathrm{~mm}$ by May 1969 and at
$16 \mathrm{~mm}$ by September 1969. The slowest growth was observed for the dense urchin population at $15 \mathrm{~m}$ depth on the coralline encrusted loose substratum at Portugal Cove. The mode at $7.5 \mathrm{~mm}$ in late June to early July 1968 advanced to $8.0 \mathrm{~mm}$ by mid-May 1969 and to $8.5 \mathrm{~mm}$ by late-August 1969, and became increasingly fused to a stationary mode at $10.5 \mathrm{~mm}$. Thus, the growth rate of the predominant group of small urchins varied considerably among the different sites. Over a 13 to 14 mo period, it showed a growth of $3 \mathrm{~mm}$ in shallow water at Logy Bay compared to a growth of $7 \mathrm{~mm}$ in shallow water at Portugal Cove and of $1 \mathrm{~mm}$ in deeper water at Portugal Cove.

Two previous field studies in the St. Lawrence Estuary, Quebec, document the growth of juvenile Strongylocentrotus droebachiensis (Himmelman et al.
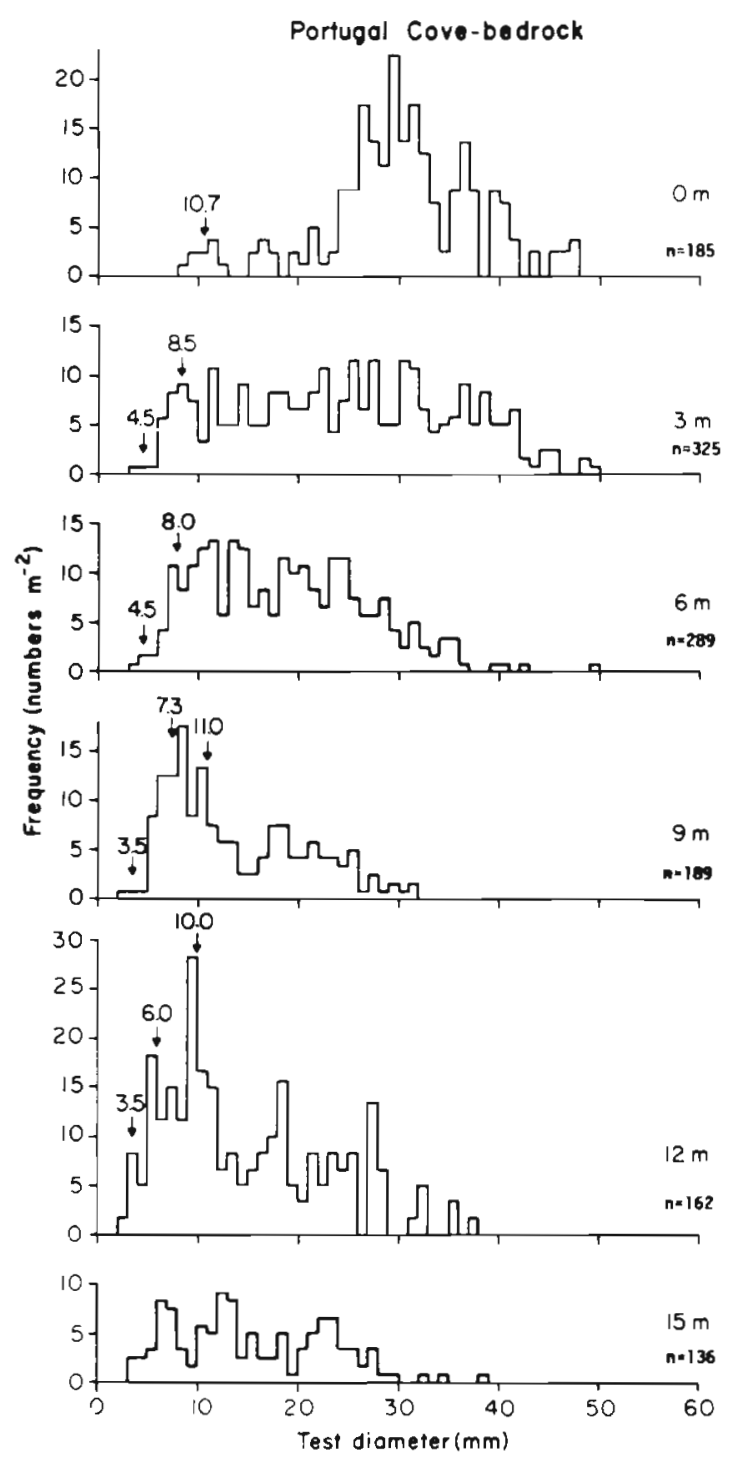

Fig. 5. Strongylocentrotus droebachiensis. Size-frequency distributions at different water depths in the transect on bedrock substratum at Portugal Cove 
$1983 a$, b). In a very dense population on loose substratum at Pointe Mitis on the south shore of the estuary a well-defined mode of urchins centered at $2 \mathrm{~mm}$ in

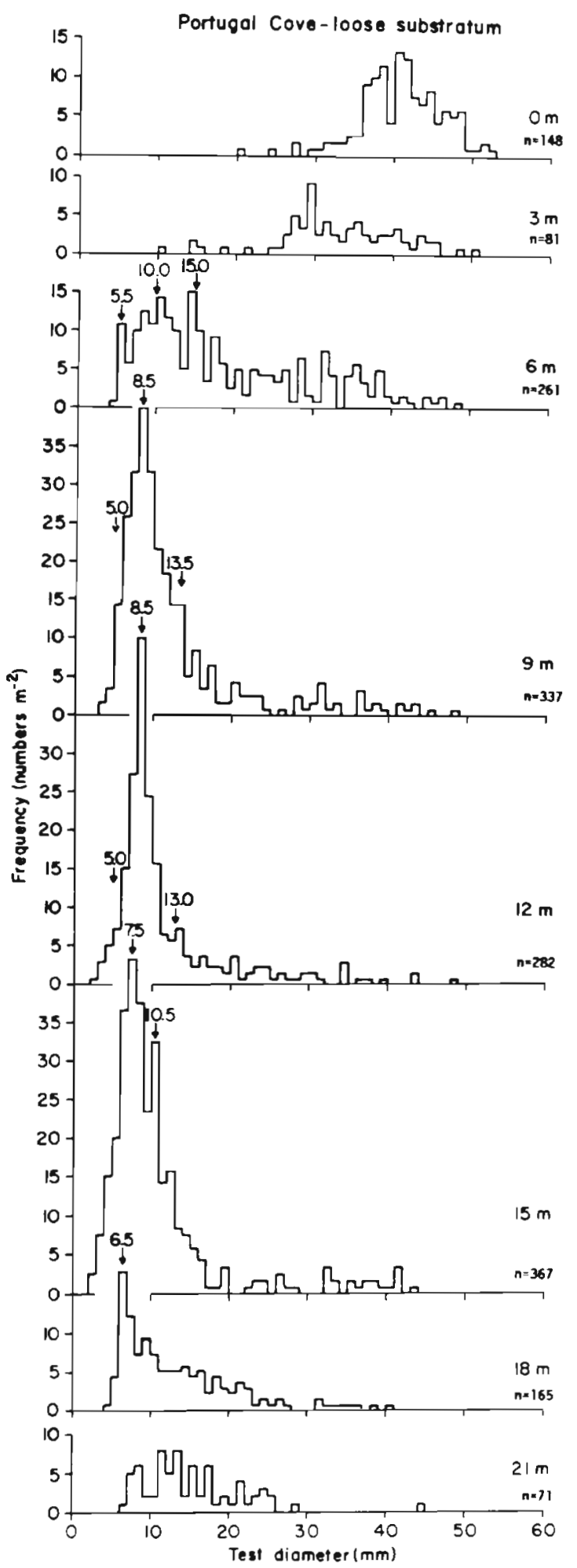

Fig. 6. Strongylocentrotus droebachiensis. Size-frequency distributions at different water depths in the transect on loose substratum at Portugal Cove
June 1978 increased to $6 \mathrm{~mm}$ by May 1981. On bedrock on the north shore of the estuary, a mode of juvenile urchins, varying from 2.8 to $4.3 \mathrm{~mm}$ depending on water depth, changed by 2 to $3 \mathrm{~mm}$ over a 2 yr period. These well-defined modes of small urchins were probably recruits from the spawning of 1977 .

In the present study, at a number of depths at Logy Bay and Portugal Cove a group of very small urchins, 3.5 to $5.5 \mathrm{~mm}$ in test diameter, was present during summer 1968 and may represent recruitment from the previous summer (Fig. 4, 5 \& 6). The next and much stronger cohort, 6.0 to $10.7 \mathrm{~mm}$ at Portugal Cove and Logy Bay, and 10 to $12 \mathrm{~mm}$ at Holyrood, is probably recruitment from $2 \mathrm{yr}$ prior to our sampling, 1966. Given the slow growth rate observed at Logy Bay, the third group at 14 to $15.5 \mathrm{~mm}$ at Logy Bay is most probably recruitment from 1964. Cohorts of larger urchins are not readily recognizable. There is much overlap of older year classes.

Size-frequency distributions showed that recruitment changes between years as well as with depth and among locations. The predominant mode, probably 1966 recruits, was present in the 4 transects but was more abundant at Logy Bay and Portugal Cove than at Holyrood. The more recent cohort, presumably 1967

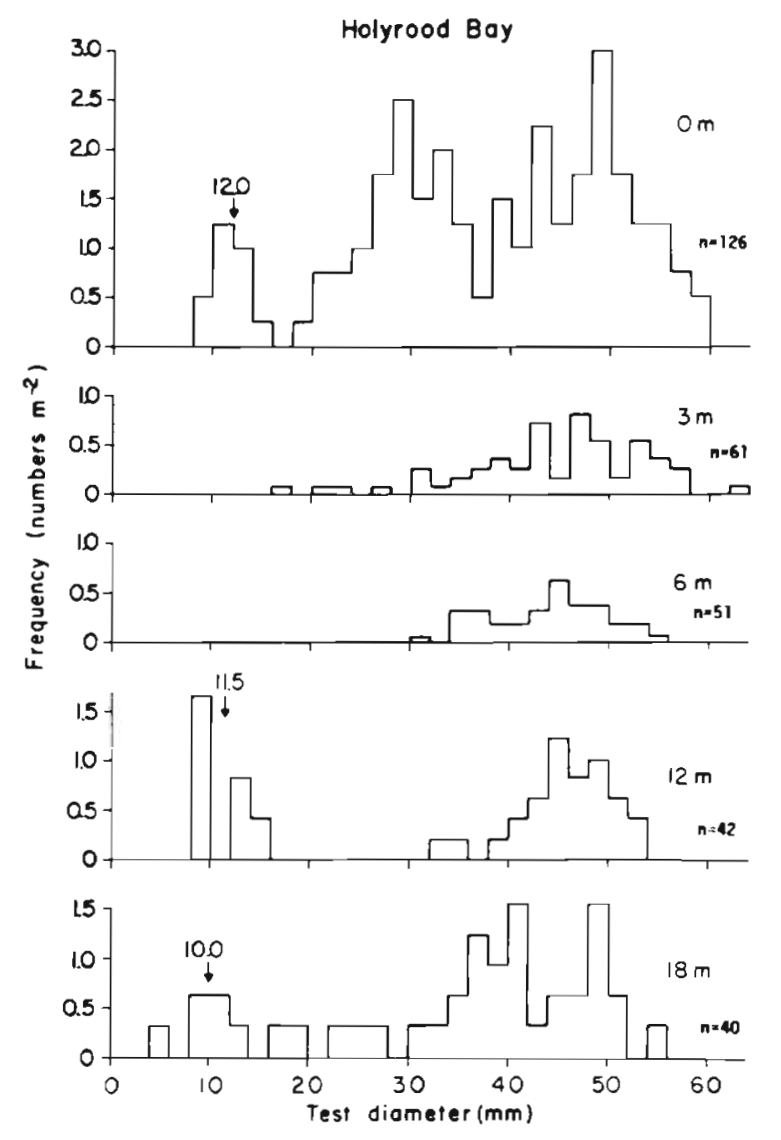

Fig. 7. Strongylocentrotus droebachiensis. Size-frequency distributions at different water depths at Holyrood Bay 
Fig. 8. Strongylocentrotus droebachiensis. Size-frequency distributions at 3 different periods at $5 \mathrm{~m}$ depth at Logy Bay, at $3 \mathrm{~m}$ depth on bedrock at Portugal Cove, and at $15 \mathrm{~m}$ depth on loose substratum at Portugal Cove
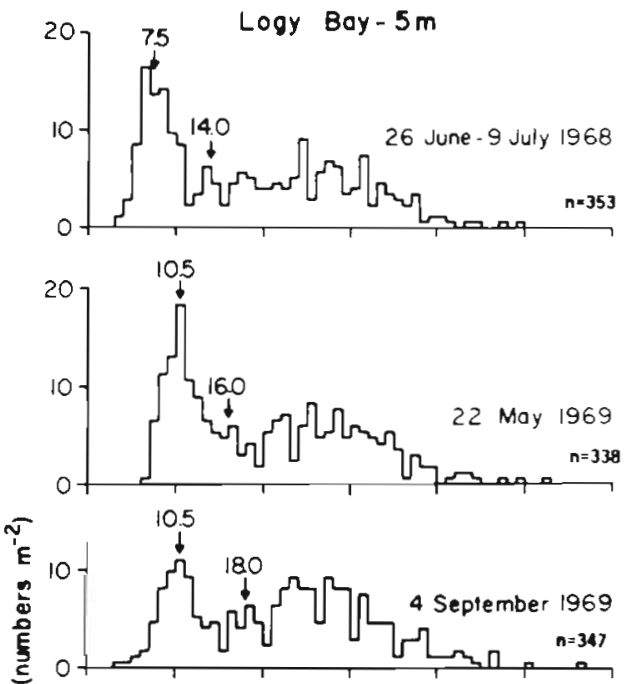

Porfugal Cove-bedrock-3m
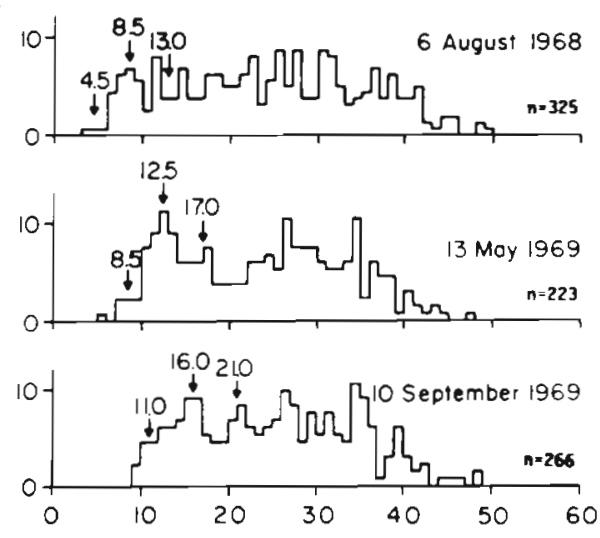
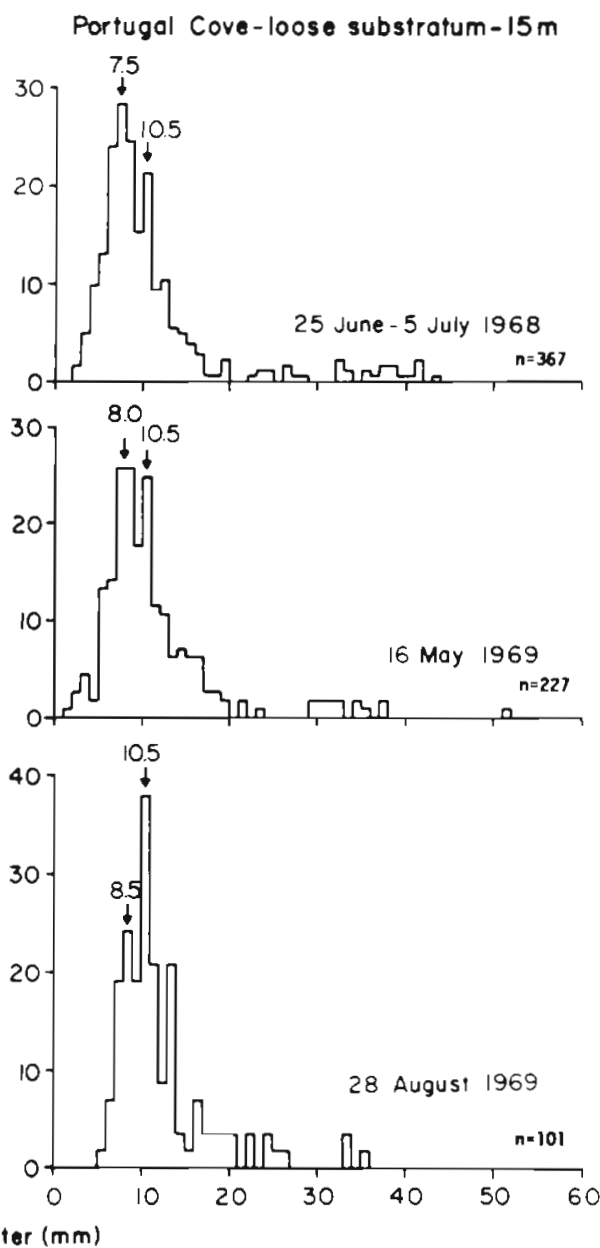

recruits, was most abundant at Logy Bay, probably present at a number of depths at Portugal Cove, and absent at Holyrood. It was much less abundant than the 1966 cohort. Urchins $<10 \mathrm{~mm}$ in diameter showed a marked decrease in abundance below 12 to $15 \mathrm{~m}$ depth at Logy Bay and Portugal Cove suggesting that urchin recruitment was concentrated in the upper $15 \mathrm{~m}$. The above sampling showed no evidence of recruitment from the spawnings during March in 1968 and April in 1969 (Himmelman 1978) (Fig. 4 to 8). However, very small urchins ( 0 to $2 \mathrm{~mm}$ ), which must have been recruits from the April 1969 spawning, were the predominant group present in 4 samples collected at $15 \mathrm{~m}$ depth on loose substratum at Portugal Cove on 18 December 1969 (own unpubl. data).

In Fig. 9 the number of urchins $\mathrm{m}^{-2}$ for $2 \mathrm{~mm}$ size classes has been averaged for the different depths in each of the 4 transects. Thus, each graph represents the size-structure for a complete transect. These mean distributions differ markedly. At Logy Bay, frequencies increased rapidly with size to a peak at about $9 \mathrm{~mm}$, the mean size of the 1966 cohort, and then decreased regularly with size suggesting steady mortality. On bedrock at Portugal Cove, mean size-frequency distribution was similar except that urchins measuring 22 to $32 \mathrm{~mm}$ were more abundant. On loose substratum at Portugal Cove, population size-structure was different due to the strong peak of small urchins and low numbers of intermediate-sized urchins. The numerical increase in individuals at about $40 \mathrm{~mm}$ could indicate an accumulation of year classes. Finally at Holyrood, the shape of the mean size-frequency distribution was almost the inverse of that at Logy Bay, as frequencies increased with increasing size. While recruitment or juvenile survival is low at Holyrood, longevity seems high.

In summary, from Logy Bay to Holyrood Bay, both the diameter of the cohort of 1966 urchins and the overall size of urchins increased. Growth of the 1966 cohort in shallow water over a 13 to 14 mo period was twice as fast at Portugal Cove than at Logy Bay. Thus, the growth rate of urchins increased from Logy Bay to 

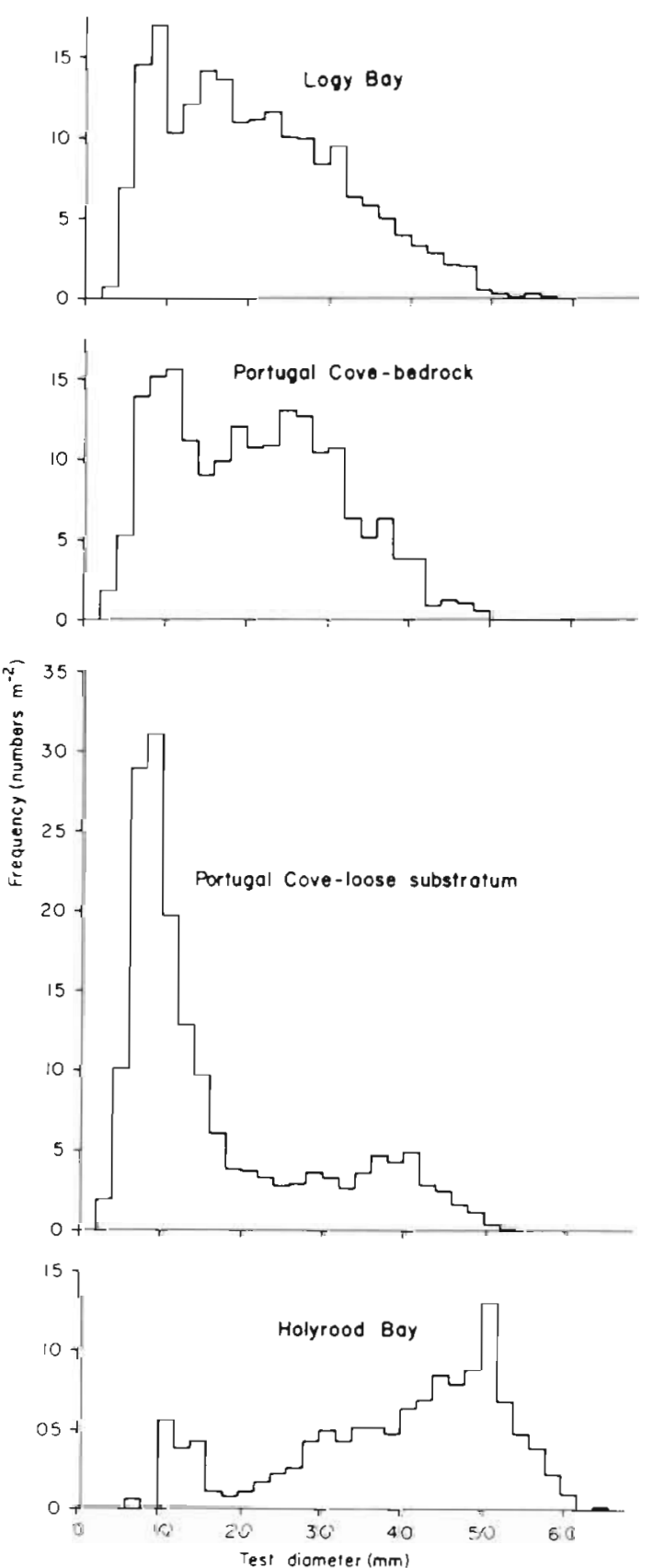

Fig. 9. Strongylocentrotus droebachiensis. Mean size-frequency distribution for each of the 4 subtidal transects taken during 1968

Holyrood Bay. While the 1966 cohort was about equally abundant on bedrock at Logy Bay and Portugal Cove, the 1967 cohort was less abundant at Portugal Cove. Only the 1966 cohort was observed at Holyrood Bay and in low numbers. Thus, a decrease in recruitment or juvenile survival going from Logy Bay and Portugal Cove to Holyrood Bay was indicated. Finally, the progressive decrease in the frequency of individuals with increasing size at Logy Bay, compared to the inverse pattern at Holyrood Bay, suggested a much higher mortality at Logy Bay than at Holyrood Bay.

\section{DISCUSSION}

Keats et al. (1984b) present data on the size structure of urchins at different depths at a more exposed site in Conception Bay located 4 to $5 \mathrm{~km}$ north of Portugal Cove. While their size distributions for 0 to $2 \mathrm{~m}$ and 12 to $18 \mathrm{~m}$ depth ranges showed erratic changes at different dates (possibly due to inadequate sampling), some temporal trends were evident at intermediate depths. For example, at 2 to $3 \mathrm{~m}$ a well-defined mode in urchins of $\approx 4 \mathrm{~mm}$ in diameter during autumn 1979 shifted to $\approx 8 \mathrm{~mm}$ by summer 1981 , to 9 to $11 \mathrm{~mm}$ by summer 1982 , and to $>13 \mathrm{~mm}$ by summer 1983 . Possibly Keats et al. could have obtained better resolution of cohorts if $1 \mathrm{~mm}$, rather than $2 \mathrm{~mm}$, size classes had been used. Thus, the study of Keats et al. shows slow growth of juveniles as I observed at Portugal Cove and Logy Bay. During their $4 \mathrm{yr}$ observation period the appearance of a group of $\approx 4 \mathrm{~mm}$ urchins in 1983 was the only new recruitment. A decrease in the abundance of small urchins ( $<10 \mathrm{~mm}$ ) below $12 \mathrm{~m}$ agrees with my observation of decreased recruitment (or juvenile survivall at greater depths. Keats et al. documented a decrease in the abundance of slow growing juveniles $(<10 \mathrm{~mm}$ ) over time and suggested that predation, particularly by cunners, was the probably cause of such mortality.

The abundance of green sea urchins in shallow water and their general decrease in abundance and size with increasing water depth has been documented by previous workers, notably by Neish (1973) and MacKay (1976) in southern New Brunswick, Propp (1964, 1966) and Kuznetzov (1946) in the eastern Murman area, and Himmelman et al. (1983b) in the St. Lawrence Estuary. Grazing aggregations of intermediate-sized and large urchins are frequently observed at the lower edge of the infralittoral algal fringe or in the lower intertidal zone in areas where the fringe is absent (Kuznetzov 1946, Himmelman 1969, 1985). The increased abundance of urchins in shallow water is probably explained by the abundance of algal food. Exceptions occur in areas where algal debris collect in deeper water. For example, larger urchins were abundant at about $13 \mathrm{~m}$ depth in the bottom of a surge channel at Logy Bay where fragments of Alaria accumulated. In locations where macrophytes or macrophyte debris are not abundant, urchin abundance drops with increasing depth.

Physical factors are probably largely responsible for the decrease in recruitment (or juvenile survival) and mortality going from Logy Bay to Holyrood Bay. The 
larvae of Strongylocentrotus droebachiensis cannot tolerate temperatures above 9 to $11^{\circ} \mathrm{C}$ (Runnström 1927, Stephens 1972) and during summer when the larvae are completing their pelagic development, high temperatures are more likely to occur in protected locations such as Holyrood Bay than at headlands such as at Logy Bay. In fact, annual temperature curves show that the spring warming is much more rapid at Holyrood Bay than at Logy Bay (Steele 1974). A mean monthly temperature of $9^{\circ} \mathrm{C}$ is reached in June at Holyrood Bay and only in August at Logy Bay. Factors associated with water movement may also favour larval survival at Logy Bay. Ebert (1982) indicates that recruitment is greatest in exposed locations for the majority of tropical urchin species. The high adult mortality at Logy Bay may be due to wave action, or to waves carrying abrasive debris. The common urchin predators, crabs, lobsters and cunners, were more frequently observed at Portugal Cove than at Logy Bay and Holyrood Bay.

The increase in growth rate from Logy Bay to Holyrood Bay is probably due to several factors. Growth frequently increases with temperature, and higher summer temperatures at Holyrood Bay may permit a higher growth rate. For echinoid populations in exposed locations, more energy must be allocated to production of a stronger body wall and to maintenance and consequently less is available for growth (Ebert 1968, 1982). Urchins from Logy Bay were difficult to detach (usually a prying tool was required) while those at Holyrood Bay were easily detached, indicating morphological and behavioural adaptations of the urchins at Logy Bay to increased water movement. Fletcher et al. (1974a) report that Logy Bay urchins from shallow water have thicker tests than those from deep water $(>12 \mathrm{~m})$. I have often noted that urchins in deep water have long delicate spines while those in shallow water, particularly in exposed sites, have short spines. Urchins from exposed sites with short spines grow long spines when maintained in the laboratory for 2 to $3 \mathrm{mo}$ (own unpubl. data). This indicates that spine breakage increases with wave exposure. Thus, the rate of growth in test diameter at Logy Bay is probably less than at Portugal Cove and Holyrood Bay because more energy is required for test production and maintenance. This may also explain the increase in size of juvenile cohorts with depth (5 to $12 \mathrm{~m}$ ) at Logy Bay (Fig. 4).

The growth rate of urchins is extremely sensitive to the type and quantity of food available (Swan 1961. Fuji 1967, Larson et al. 1980, Keats et al. 1984a). For example, under favourable food conditions Strongylocentrotus droebachiensis can grow by 10 to $20 \mathrm{~mm}$ annually (Swan 1961), whereas when food is scarce, as it is at $15 \mathrm{~m}$ depth on loose substratum at Portugal Cove, growth is negligible. In very dense urchin popu- lations, such as at Logy Bay and Portugal Cove, where urchins severely overgraze the subtidal community, food must be very limited. By contrast, at sites with a low urchin density such as Holyrood Bay food availability should be greater. Increased food availability, due to decreasing urchin numbers, was considered to be the most plausible explanation of increased urchin growth rates at different locations (with similar exposure to waves) going up the St. Lawrence Estuary (Himmelman et al. 1983b). Thus, lower temperatures, increased allocation of energy to processes other than growth in diameter, and decreased food availability could all contribute to the decrease in growth of $S$. droebachiensis from Holyrood Bay to Logy Bay.

Within dense urchin populations, favourable macroalgal foods are rare and there is strong intraspecific competition (Himmelman et al. 1983a). In the dense urchin populations just below the Alaria fringe at Logy Bay and Portugal Cove, juvenile urchins showed an annual growth of 3 and $7 \mathrm{~mm}$, respectively. At $15 \mathrm{~m}$ depth on the loose substratum at Portugal Cove, further from the shallow water zone of macroalgal production, juvenile urchins exhibited an annual growth of only $1 \mathrm{~mm}$. Juvenile Strongylocentrotus droebachiensis can grow much faster when provided with food. For example, over a 1 yr period Swan (1961) observed a growth from 5 to $15 \mathrm{~mm}$ for urchins fed Ascophyllum nodosum, and from 5 to $22 \mathrm{~mm}$ for urchins fed Laminaria spp. Thus, while juvenile urchins can grow $17 \mathrm{~mm}$ annually under optimal conditions, their growth rate is strongly influenced by nutritional conditions and when food is very scarce, as is usually the case in dense urchin populations on barrens, growth rate may drop to 1 to $2 \mathrm{~mm}$ annually.

Previous studies of field populations, with the exception of that of Keats et al. (1984b), suggested much higher growth rates for juvenile urchins. Swan (1958) examined the size-structure of urchins in a low intertidal pool in Maine in June 1957. There were 2 predominant modes of urchins - one centered at $9 \mathrm{~mm}$, the other at $25 \mathrm{~mm}$. He suggests these were the 1956 and 1955 recruitments. Favourable algal foods were abundant near this pool. Swan $(1958,1961)$ also noted 0.5 to $1.5 \mathrm{~mm}$ urchins which he considered the recruitment from the same year. Similarly, in subtidal collections in the Folden Fjord, Norway, Greig (1928) found Strongylocentrotus droebachiensis measuring 0.5 to $2.5 \mathrm{~mm}$ which he considered to be recruits from the same year, and a mode at 5 to $6 \mathrm{~mm}$ which he considered to be individuals from the previous year. Miller \& Mann (1973) reported the population size-structure of urchins in St. Margaret's Bay, prior to the disappearance of kelps from the region. No well-defined cohorts were present, but using growth rates of urchins fed in the laboratory and the postulate of an autumn and spring 
spawning period, they identified cohorts in this population. Their assumption of 2 spawning periods is unlikely since only one annual spawning has been observed in numerous other locations (Himmelman 1978). Lang \& Mann (1976) and Wharton \& Mann (1981) examined growth lines of urchins on barrens (where there have been no kelp for 3 to $4 \mathrm{yr}$ ) and report that 2 yr old individuals measure 15 to $20 \mathrm{~mm}$. This seems improbable given how a scarcity of food limits the growth of urchins.

While in the present study I have good observations on the growth of juveniles, I have no information on that of intermediate-sized and large urchins $(>20 \mathrm{~mm})$ since cohorts of larger urchins were not recognizable (and one would not expect them to be given the great overlap of even juvenile year classes) and no examination was made of growth lines. Fletcher et al. (1974a) measured the relation between test diameter and number of growth lines for the population of urchins at Logy Bay. Urchins having one growth line measured $\approx 17 \mathrm{~mm}$ in diameter and were classified as $1+$ yr old. With each additional growth line up to the age of $4+\mathrm{yr}$ there was an increase in diameter of $\approx 6$ to $7 \mathrm{~mm}$. This indicates a much greater growth rate for large than for small urchins. Miller \& Mann (1973) and Lang \& Mann (1976), using growth line analysis, indicated a similar or greater annual increase for intermediate-sized urchins in Nova Scotia, Canada.

Growth lines in urchins are often difficult to interpret (Pearse \& Pearse 1975, Breen \& Adkins 1976) and it is probable that annual growth lines are particularly difficult to recognize for slow-growing juveniles. The workers who studied Strongylocentrotus droebachiensis in dense populations may have counted the growth increment of the entire juvenile period as one growth line and thus obtained their low estimates of age in relation to size. Annual growth lines should be more recognizable with the onset of sexual maturity at 20 to $30 \mathrm{~mm}$ in diameter (Himmelman 1969, 1978, Fletcher et al. 1974a), since there is a pronounced slowing of growth during the winter when more energy is being channeled into gonadal growth (Miller \& Mann 1973, Larson et al. 1980).

I propose that in dense populations the growth rate of urchins is not a regular function of size but rather that juveniles grow very slowly and after reaching a test diameter of 15 to $20 \mathrm{~mm}$ undergo a behavioural change and grow quickly. Small urchins are particularly abundant in crevices, as seen on the Lithothamnium-encrusted bottom at Portugal Cove in the present study (Fig. 3) and on the pebble and cobble bottom at Pointe Mitis (Himmelman et al. 1983b). Possibly crevices act as refuges against predation by certain species of fish, such as the cunner and winter flounder (Himmelman \& Steele 1971, Martel 1983), and possibly by small crabs and lobsters. Small urchins are probably sedentary. This was clear from a recent experimental study on an urchin-dominated barrens in the northern Gulf of St. Lawrence (Nédélec \& Himmelman unpubl.). Of Alaria esculenta, $60 \mathrm{~g}$ portions were anchored on the bottom at a site where the urchin population closely resembled that on the loose substratum population at $15 \mathrm{~m}$ depth at Portugal Cove; $24 \mathrm{~h}$ later $0.25 \mathrm{~m}^{2}$ quadrats were placed over the anchored algae and all urchins in contact with the algae or visible within the quadrats were collected. While complete sampling showed that $71 \%$ of the urchins in the site measured $<15 \mathrm{~mm}$ in diameter, $94 \%$ of the urchins collected in the above manner measured $>15 \mathrm{~mm}$. The density of $>15 \mathrm{~mm}$ urchins in quadrats with $A$. esculenta increased by a factor of 6 . Similar results were obtained with other macroalgae which were preferred urchin foods. Thus, larger urchins moved rapidly towards the algae while small urchins remained largely hidden in crevices and did not move towards the algae. Detritus, and possibly microalgae, rather than macroalgae are probably the main foods of juveniles. Using gut analysis, Fuji (1967) showed this for the related urchin Strongylocentrotus intermedius. S. droebachiensis larger than $20 \mathrm{~mm}$ move about actively in search of food and are often found browsing at the lower edge of the shallow water algal zone or on pieces of algae which fall to the bottom at greater depths. Laboratory studies have demonstrated that larger urchins have marked food preferences. They use chemoreception to locate preferred foods such as species of Alaria and Laminaria, whereas they display little interest in algae such as Agarum spp. and Ptilota serrata (Himmelman 1969, 1985, Vades 1977, Larson et al. 1980). Urchins grow more rapidly when fed preferred foods (Vades 1977, Larson et al. 1980, Keats et al. 1984a). Thus, it appears that when food is rare, larger urchins because of their greater mobility and ability to detect and locate macroalgae - can have higher growth rates than juveniles.

During the 14 mo observation period of the dense population at $15 \mathrm{~m}$ on loose substratum at Portugal Cove a mode at $7.5 \mathrm{~mm}$ in June 1968 gradually became incorporated into a stationary mode at $10.5 \mathrm{~mm}$. The same situation was observed in the dense population of small urchins at Pointe Mitis in the St. Lawrence Estuary (Himmelman et al. 1983b). Over a $3 \mathrm{yr}$ period a mode initially observed at $2 \mathrm{~mm}$ in diameter fused with a static mode at 8 to $9 \mathrm{~mm}$. These observations suggest that when food is scarce small urchins, because of their sedentary behaviour, do not grow beyond a certain size. Thus, a static mode of small urchins, which represents an accumulation of year classes, is formed. The size of this conglomerate mode may vary. For example, at Pointe Mitis in the study of 
Himmelman et al. (1983b, 1984) the size of the static mode decreased with increasing distance from the intertidal zone. A mortality of larger individuals would permit a greater macroalgal food availability and permit some juveniles to become foraging adults. In fact, much of the persistence of urchin-dominated communities (Himmelman et al. 1983a, b) is probably due to the continual replacement of mortalities among the foraging adults by the ever abundant juveniles. Thus, a high grazing pressure and a paucity of algae and invertebrates sensitive to urchin grazing is maintained. Only a mass mortality of all urchin sizes, as could be caused by a disease and which occurred on the Nova Scotian coast the early 1980's (Miller \& Colodey 1983, Miller 1985a, b), could change an urchindominated barrens to a kelp community

In summary, urchin populations appear to have 2 components. The first comprises small individuals which are relatively sedentary and probably rely largely on detrital food brought to them by currents. Where food is scarce their growth is slow and in very dense populations it may almost stop at certain size. This causes the formation of a stationary conglomerate mode of juveniles at 8 to $11 \mathrm{~mm}$ in test diameter, probably depending on the severity of the food shortage. The second component consists of $>15$ to $20 \mathrm{~mm}$ urchins which actively move about to forage on macrophytes and thus have an increased growth rate. With increasing size their growth also slows and in habitats where there little mortality they too form a conglomerate mode. The position of this adult mode probably largely reflects the availability of macroalgal food but may also be influenced by maintenance requirements, as in exposed habitats where energy must be allocated to spine repair (Ebert 1968). Any particular habitat may only be able to support a given number or biomass of larger urchins. When there is a sudden decrease in the availability of macrophytes, as sometimes occurs in late summer, there may be cannibalism, as observed by Himmelman \& Steele (1971).

While an increase in growth rate with increasing body size is not characteristic of most animal species, similar situations have been reported and one which bears a number of similarities with the urchin is that of ferox trout in oligotrophic Scottish lakes (Campbell 1979). Ferox trout grow slowly during the first third of life and again after reaching a critical size enter a phase of rapid growth. As in the case for the urchin, change in growth rate is due to a change in foraging habits. The trout switch from feeding mainly on invertebrates to feeding on a more abundant food source, charr. It has also been reported that the growth of juvenile Mytilus edulis ( $<3 \mathrm{~mm}$ shell length) can be suppressed by larger individuals which, because of their size, are more effective in capturing planktonic food (Kautsky 1982a, b). This occurs in the Baltic Sea where there are no mussel predators and populations become extremely dense, being limited mainly by intraspecific competition.

Acknowledgements. I thank H. Guderley, D. H. Steele, D. Keats, M. Fréchette, and L. Gendron for critical reading my $\mathrm{ms}$, and P. Joly for preparing the figures. Field work was supported by a NRCC grant to D. H. Steele; later analysis by a NSERC grant to J.H.H.

\section{LITERATURE CITED}

Breen, P. A., Adkins, B. E. (1976). Growth rings and age in the red sea urchin, Strongylocentrotus franciscanus. Fish. Res. Bd Can. MS Rep. Ser. No. 1413

Breen, P. A., Mann, K. H. (1976). Destructive grazing of kelp by sea urchins in eastern Canada. J. Fish. Res. Bd Can. 33: 1278-1283

Campbell, R. N. (1979). Ferox trout, Salmo trutta L., and charr, Salvelinus alpinus (L.), in Scottish lochs. J. Fish. Biol. 14: $1-29$

Ebert, T. A. (1968). Growth rates of the sea urchin Strongylocentrotus purpuratus related to food availability and spine abrasion. Ecology 49: 1075-1091

Ebert, T. A. (1982). Longevity, life history, and relative body wall size in sea urchins. Ecol. Monogr. 52: 353-394

Fletcher, G. L., Pepper, V. A., Kean, J. C. (1974a). A study of the biology of the Newfoundland sea urchin with emphasis on aspects important to the development of a fishery, Mar. Sci. Res. Lab., Tech. Rep. No. 11, Memorial Univ. Newfoundland, St. John's, Canada

Fletcher, G. L., Scaplen, R. P., Buggln, R. C., Idler, D. R. (1974b). A survey of the inshore marine resources of Fortune Bay, l'Anse au Loup Bay, Pinware Bay and Red Bay, Labrador, with particular emphasis on shellfish, sea urchins and seaweeds. Mar. Sci. Res. Lab., Tech. Rep. No. 9, Memorial Univ. Newfoundland, St. John's, Canada

Foreman, R. E. (1977). Benthic community modification and recovery following intensive grazing by Strongylocentrotus droebachiensis. Helgoländer wiss. Meeresunters. 30: $468-484$

Fuji, A. (1967). Ecological studies on the growth and food consumption of Japanese common littoral sea urchin, Strongylocentrotus intermedius (A. Ågassiz). Mem. Fac. Fish. Hokkaido Univ. 15: 83-160

Grieg, J. A. (1928). The Folden Fjord. Echinodermata. Tromso Mus. Skr. $1(7)$ : 1-12

Hagen, N. T. (1983). Destructive grazing of kelp beds by sea urchins in Vestfjorden, northern Norway. Sarsia 68: $177-190$

Himmelman, J. H. (1969). Some aspects of the ecology of Strongylocentrotus droebachiensis in eastern Newfoundland. M. Sc. thesis, Memorial Univ. Newfoundland, Canada

Himmelman, J. H. (1978). Reproductive cycle of the green sea urchin, Strongylocentrotus droebachiensis. Can. J. Zool. 56: $1828-1836$

Himmelman, J. H. (1985). Urchin feeding and macroalgal distribution in Newfoundland, eastern Canada. Nat. Can. 111: $337-348$

Himmelman, J, H., Cardinal, A., Bourget, E. (1983a). Community development following removal of urchins, Strongylocentrotus droebachiensis, from the rocky subtidal 
zone of the St. Lawrence Estuary, eastern Canada. Oecologia 59: 27-39

Himmelman, J. H., Lavergne, Y. (1985). Organization of rocky subtidal communities in the St. Lawrence Estuary. Nat. Can. 112: $143-154$

Himmelman, J. H., Steele, D. H. (1971). Foods and predators of the green sea urchin Strongylocentrotus droebachiensis in Newfoundland waters. Mar. Biol. 9: 315-322

Himmelman, J. H., Lavergne, Y., Axelsen, F., Cardinal, A., Bourget, E. (1983b). Sea urchins in the Saint Lawrence Estuary: their abundance, size-structure, and suitability for commercial exploitation. Can. J. Fish. Aquat. Sci. 40; $474-486$

Himmelman, J. H., Lavergne, Y., Axelsen, F. (1984). L'abondance et la structure des populations d'Oursin vert, Strongylocentrotus droebachiensis, dans l'estuaire du Saint Laurent. Ministère de l'Agriculture, des Pêcheries et de l'Alimintation, Québec, Direction générale des pêches maritimes, Cahiers d'Information 109

Hooper, R. (1980). Observation on algal-grazer interactions in Newfoundland and Labrador. In: Pringle, J. D., Sharp, G. J., Caddy, J. F. (ed.) Proceedings of the workshop of the relationship between sea urchin grazing and commercial plant/animal harvesting. Can. Tech. Rep. Fish. Aquat. Sci. No. 954: 120-124

Kautsky, N. (1982a). Growth and size structure in a Baltic Mytilus edulis population. Mar. Biol. 68: 117-133

Kautsky, N. (1982b). Quantitative studies on gonadal cycle, fecundity, reproductive output and recruitment in a Baltic Mytilus edulis population. Mar. Biol. 68: 143-160

Keats, D. W., Steele, D. H., South, G. R. (1984a). Depthdependent reproductive output of the green sea urchin, Strongylocentrotus droebachiensis (O. F. Müller), in relation to the nature and availability of food. J. exp. mar. Biol. Ecol. 80: 77-91

Keats, D. W., South, G. R., Steele, D. H. (1984b). Ecology of juvenile green sea urchins (Strongylocentrotus droebachiensis) at an urchin dominated sublittoral site in eastern Newfoundland. Proc. 5th Int. Echinoderm Conference. Galway, 24-29 September 1984. Balkema Press, Rotterdam, p. 295-302

Keats, D. W., South, G. R., Steele, D. H. (1985). Algal biomass and diversity in the upper subtidal at a pack-ice disturbed site in eastern Newfoundland. Mar. Ecol. Prog. Ser. 25: $151-158$

Kuznetzov, V. V. (1946). Nutrition and growth of herbivorous marine invertebrates in the eastem Murman. Bull. Acad. Sci. USSR, Biol. 4: 431-452 (In Russian)

Lang, C., Mann, K. H. (1976). Changes in sea urchin populations after the destruction of kelp beds. Mar. Biol. 36: 321-326

Larson, B. R., Vadas, R. L., Keser, M. (1980). Feeding and nutritional ecology of the sea urchin Strongylocentrotus droebachiensis in Maine, USA. Mar. Biol. 59: 49-62

Lawrence, J. M. (1975). On the relationships between marine plants and sea urchins. Oceanogr. mar. Biol. A. Rev. 13: 213-286

MacKay, A. A. (1976). The sea urchin roe industry on New Brunswick's Bay of Fundy coast. Marine Research Associates Report to the New Brunswick Department of Fisheries, Fredericton, New Brunswick, Canada
Madsen, H. (1936). A study of the littoral fauna of northwest Greenland. In: The natural history expedition to northern Greenland 1936. Meddr Grenland 124: 1-24

Martel, G. (1983). Sexual selection and territory size in male cunners (Tautogolobrus adspersus) (Walbaum) in Conception Bay, Newfoundland. M. Sc. thesis, Memorial University of Newfoundland, St. John's

Miller, R. J. (1985a). Succession in sea urchin and seaweed abundance in Nova Scotia, Canada. Mar. Biol. 84: 285-286

Miller, R. J. (1985b). Sea urchin pathogen: a possible tool for biological control. Mar. Ecol. Prog. Ser. 21: 169-174

Miller, R. J., Mann, K. H. (1973). Ecological energetics of the seaweed zone in a marine bay on the Atlantic coast of Canada. III. Energy transformations by sea urchins. Mar. Biol, 18: 99-114

Miller, R. J., Colodey, A. G. (1983). Widespread mass mortalities of the green sea urchin in Nova Scotia, Canada. Mar. Biol. 73: 263-267

Neish, I. C. (1973). The distribution of sea urchins in Charlotte County, New Brunswick. Report to the New Brunswick Department of Fisheries and Environment, Fredericton, New Brunswick, Canada

Pearse, J. S., Pearse, V. B. (1975). Growth rings in the echinoid skeleton. Am. Zool. 15: 731-753

Propp, M. V. (1964). Application of statistics to ecological studies of sublittoral invertebrates. In: New investigations on the plankton and benthos of the Barrents Sea. Akademia Nauk USSR, Murman Marine Biological Institute 6 (10): 76-87 (In Russian)

Propp, M. V. (1966). Composition and distribution of plankton and benthos in the southern part of the Barrents Sea. Akademia Nauk USSR, Murman Marine Biological Institute 11 (15): 92-114 (In Russian)

Runnström, S. (1927). Über die Thermopathie der Fortpflanzung und Entwicklung mariner Tiere in Beziehung zu ihrer geographischen Verbreitung. Bergens Mus. Árb. Naturvitensk Rekke, 1927, 2: 1-67

Shelford, V E., Weese, A. O., Rise, L. A., Rusmussen, D. I., MacLean, A. (1935). Some marine biotic communities of the Pacific coast of North America. Part 1. General survey of the communities. Ecol. Monogr. 5: 249-332

Steele, D. H. (1974). Temperature and salinity cycles at the Marine sciences Research Laboratory, Logy Bay, Newfoundland. Mar. Sci. Res. Lab., Tech. Rep. No. 12: 1-21

Stephens, R. E. (1972). Studies on the development of the sea urchin Strongylocentrotus droebachiensis. I. Ecology and normal development. Biol. Bull. mar. biol. Lab., Woods Hole 142: 132-144

Swan, E. F. (1958). Growth and variation in sea urchins of York, Maine. J. mar. Res. 17: 505-522

Swan, E. F. (1961). Some observations on the growth rate of sea urchins in the genus Strongylocentrotus. Biol. Bull. mar. biol. Lab., Woods Hole 120: 420-427

Wharton, W. G., Mann, K. H. (1981). Relationship between destructive grazing by the sea urchin, Strongylocentrotus droebachiensis, and the abundance of American lobster Homarus americanus, on the Atlantic coast of Nova Scotia. Can. J. Fish. Aquat. Sci. 38: 1339-1349

Vadas, R. L. (1977). Preferential feeding: an optimization strategy in sea urchins. Ecol. Monogr. 47: 337-371 